
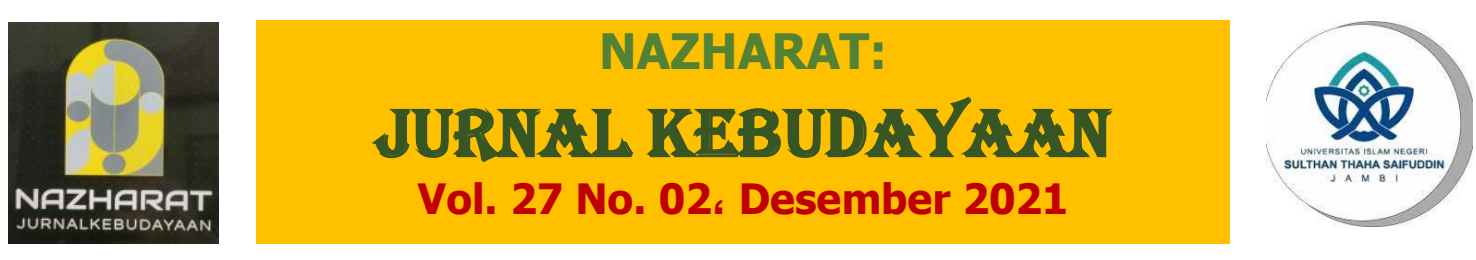

\title{
GENDER INEQUALITY BEFORE THE LAWS AS SEEN IN ON THE BASIS OF SEX FILM BY MIMI LEDER
}

\author{
Fuji Lestari, Bahren, Yenti \\ UIN Sultan Thaha Saifuddin Jambi \\ yenti@uinjambi.ac.id
}

In this study, researcher analyzes an inequality film written by Daniel Stiepleman and directed by Mimi Leder. This Film tells the strory about inequality dan women struggle. Therefore the researcher entitled this research with "Gender Inequality before the Laws as seen in On the Basis Of Sex film by Mimi Leder", This study aimed to discuss; 1) injustice between a man and a woman before the law, 2) how women try to resist the laws. Design of this research was qualitative descriptive research. The researcher applied the theory of human rights and feminist legal theory by Universal Decralation of human right and Judith and remer to answer the research question problem formulation. Sociological approach also used in this research. In collecting the data, the researcher used technique of documentation. The technique used in analyzing data in this study was a descriptive technique. The results of this research are; 1) there are four gender inequalities depicted in the film on the basis of sex; (a) inequality in economic right (b) inequality in education right (c) inequality in social right (d) inequality in civil right 2) women's efforts to fight the law are three ways (a) Speak Out the Own Experiences (b) support other campaigners (c) exspressing rational opinions.
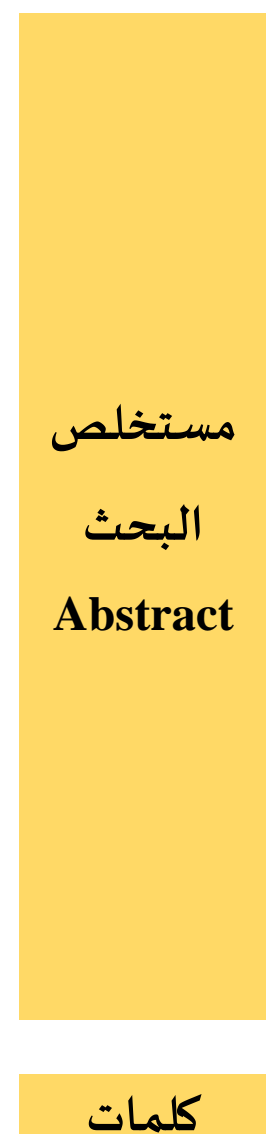

أسـاسية

Keyword

\section{INTRODUCTION (مقدمة)}

Film is predetermined by literary technique conversely, literary practice developed particular features under the impact film. It functions as entertain media, education and the light. It means that, the creation of a film can't be separated from the influence of literary technique; many literary practices affect certain features in a film. Like as other literary work and also film great deal of pleasure to great many people does not necessarily that they are significant from the culture and historical evidence. But the fact 
they reach a mass audience signifies that film do connect with some part of the conscious experience of the general public or, at least, a large proportion of it, literary aspect in film is scenario.

Based on this true story, one feminist figure is Ruth Bader Ginsburg. She is the Supreme Court Justice in the American Supreme Court. She also managed to pass to study law at Harvard. In her past, what she did was part of breaking tradition. Not only that. She has become a role model for women who are pursuing law education because of her extraordinary career achievements. Ruth is also proof that a feminist as well as a mother and wife is able to carry out their roles well, supported by a good support system. Laws that discriminate against women may be ignored by people. But if the law is also detrimental to men, she has the opportunity to show everyone how dangerous discrimination on the basis of sex is.

Human rights are fundamental rights that humans have. Human rights are not given by the state but are protected by the state because essentially human rights are inherent in humans themselves. One of the principles of the state is the protection of human rights for every citizen. Human Rights are a tangible form of moral and legal responsibility to uphold and promote human rights. Human rights are part of the principles that come from values, then become a rule that regulates human behavior in social interaction with other humans.

The Universal Declaration of Human Rights said that the peak of the conceptualization of human thought in translating the nature and existence of oneself as a person, a member of society, a citizen of the nation, and even a citizen of the world. Based on this explanation, it can be concluded that human rights are the basic form of human beings themselves. Human rights are inherent in humans as long as they are humans. Given that human rights are inherent in every human being, then naturally everyone has the right to obtain and defend their rights as a human being, even it is their responsibility as a human being. Rights are something that must be obtained. In relation to the acquisition of rights, there is a theory, namely the theory of Anthony Flew. Rights are fundamental to human life and life and are natural rights that cannot be separated from and in human life. Then it is divided into economic rights, education, social rights, cultural rights, civil and political rights: 


\section{a. Economic Right}

Economic rights are a legal instrument that regulates the protection and fulfillment of human rights in the economic field. Every citizen has the right to work and a decent living for humanity and everyone have the right to work and receive fair and proper remuneration and treatment in a working relationship.

\section{b. Education Right}

Basic education is part of the human right for everyone to gain improvement and progress both in the fields of knowledge, skills, as well as attitudes and morals. The affirmation of the right to basic education is contained in the Universal Declaration of Human Rights "Everyone has the right to education. Education shall be free, at least in the elementary and fundamental stages. Elementary education shall be compulsory. Technical and professional education shall be made generally available and higher education shall be equally accessible to all on the basis of merit".

\section{c. Social Right}

Human rights specifically in the social field Basically this right arises because of discrimination. Social rights are human rights related to social security. "Everyone has the right to live in physical and spiritual prosperity, to live and to have a good and healthy living environment". Collective rights are not owned by individuals or individuals but are owned by a community of people in a sovereign state. Social rights also guarantee the right to work and get decent work.

\section{d. Cultural Right}

Everyone has the right to develop themselves through the fulfillment of their basic needs, have the right to education and benefit from science and technology, arts and culture to improve the quality of life and human welfare. The state advances culture by guaranteeing freedom of society in maintaining and developing valuesthe culture. Everyone's right to participate in life culture, enjoy the benefits of science and its application, enjoy protection of the moral and material interests of a scientific, literary or product art created.

\section{e. Civil Right}


Civil rights are fundamental freedoms that are obtained as the essence of the existence of a human being. Civil rights that exist in every country are guaranteed constitutionally. Universal civil rights known to a person are freedom of speech, thought and expression, religion, and a fair and impartial trial. Civil rights include ensuring people's physical integrity and safety, protection from discrimination on grounds such as physical or mental disability, gender, religion, race, national origin, age, or sexual orientation, and individual rights such as freedom of thought and conscience, peech and expression, religion and the press as well as the right to equality before the law, the right to equal protection of the law without discrimination.

\section{f. Political Right}

Political rights are basic and absolute rights inherent in every citizen that must be upheld and respected by the state under any circumstances. Political rights are part of the right to personal freedom, which is a right where a person must use his political rights freely. Political rights are related to the right to participate in government, especially the right to vote, related to conscience so that the use of the right to vote must be carried out freely without pressure and coercion.

Women have experienced discrimination as a result of a false system that views women as second class in civilization. Then, the role of feminism becomes a tool to make women aware of the wrong system to escape from gender discrimination.It can be interpreted that feminism has two goals; creating a social group for rejecting the unfair social systems, and gaining a freedom for every people to determine theirself.

According to Judith and Remer : Feminists understand that the feminism movement is based on women's knowledge. Women are frequently subjected to oppression and exploitation and this oppression and exploitation must end. Furthermore, the feminism movement aspires to fight for women's equality and dignity in the workplace, as well as the right to manage their own bodies and lives both within and outside the workplace.

If women's struggle want to achive gender equality then society must give women the same political, oppurtunity and educational right as men by freeing women to choose what men have and vice versa so that women can have the same high education with men. It means that equality then society must give women the same political, 
opportunity and educational rights as men, because women can be have the same high education with men. Although liberals define reason in general in moral terms they agree that a just society will enable an individual to satisfy himself.

\section{THEORITICAL FRAMEWORK (نظريات)}

\section{The Efforts to Fight the Injustice}

Women go through many problems, obstacles, and barriers to become important members of society. It is important to note that there are dangers associated with the behavior of calling out to others. People may not like it when their point of view is challenged. They may react in a negative or aggressive manner, so if our instincts tell us that a situation is too risky, our own safety is the priority. This means that women need feminism because there are women who experience injustice. Then, the role of feminism becomes a tool to make women aware of the wrong system in order to escape from injustice.

A great way to make a big effect in the pursuit of gender equality is to join with others. Seek out local campaign groups. Join or set up school or university societies for gender equality and female leadership. There is strength in numbersmore voices tackling a particular issue means they are more likely to be heard. Helping to raise the profile of campaigns by other marginalised groups is a vital part of ending discrimination. For example, girls from a minority or indigenous community may experience racism as well as sexism. Be their allies and lend ourvoice to their causes.

The basic of women's problems related gender roles in the society are the women's powerlessness to face the male supremacy and the strong patriarchal system as the social system. since the porpotion of women who are full-time housewives has fallen dramatically over first wave feminism, as the proportion of women in paid work has increased. It shows a reduction in the time spent on housework. This lead any significant increase in housework to lead the family by women. Economical dependence of women to men is one cause of male supremacy is very strong. After the first-wave, they get a lot of chance to determine their own, including finding a job. Given the opportunity, they can have a career in public spaces, so that they can be independent to men. By having a career, women are regarded that they can participate in the family. One of the family participation is that women can be decision-makers for the family. The opportunity to participate 
outside household is an opportunity to replace men's roles that are constructed by society.

A women stereotype is that women always use their feelings to face the problems. woman often shows she is capable of practising; she has a good conscience because she is on the unprivileged side; she feels she is under no obligation to deal gently with the favoured caste, and her only thought is to defend herself. The problem is that women are not given a chance to prove that they are able to think logically. For that reason, they must prove it. Women's distress affects they must prove to society that they could have the capability to express opinions rationally. women must express their opinions in order to protect themselves from the dicrimination they experienced.

\section{METHOD (طريقة \منهج البحث)}

Qualitative research is a research procedure that produces descriptive data in form of written words and from people that can be observed. It means that, characteristic of the qualitative analytic and produce descriptive data spoken word of the person or behavior being researched. Qualitative research is multi method in focus, involving an interpretive, naturalistic approach to its subject matter. This means that qualitative researchers study thing in their natural settings, attempting to make sense of or interpret phenomena in terms of the meanings people bring to them. Qualitative research involves the studied use and collection of a variety of empirical materials-case study, personal experience, introspective, life story, interview, observational, historical, interactional, and visual texts-that describe routine and problematic moments and meaning in individuals' lives.

The researcher used qualitative descriptive method to explain the materials because it analyzed the nature of objects, to describe a situation systematically, problem, phenomenon, or provide information about living condition of a community, or describe attitude towards an issue. So, the data analysis explained in form of picture and word.In this research the researcher focused on one feminist figure is Ruth Bader Ginsburg in on the basis of sex film.

\section{FINDINGS \& DISCUSSION (بحث ومناقشة)}

In economic rights, every human being has the freedom to get a job. But here, Ruth tells how difficult it is for her and women to find decent work. One example in this 
conversation, Ruth is talking about a female attorney who has qualified as a lawyer but is not permitted. This conversation shows the inequality of rights in the economy.

Ruth: A hundred years ago, Myra Bradwell wanted to be a lawyer. She had fulfilled the requirements for the Illinois bar, but she wasn't allowed to practice because she was a women.

The conversation explained the difficulty of getting a job for women. the dialogue explained that from the beginning even though women had sufficient conditions to get a job, in fact, it was difficult to be accepted in a job. What should be women as human beings have the right to have a good job and good wages.

In this research, the researcher found that there is an educational inequality for taking a degree if you want to move to a different university. It can be seen from the dialog below:

Mr. Erwin Griswold : you would do well, Mrs. Ginsburg to remember how fortunate you are to be here.

Ruth : Dean Griswold, between the first and third year of law school. Which is the more substantive, the more critical?

Mr. Erwin Griswold: The first, of course.

Ruth : Yet, when someone transfers in as a second year student having taken those more

important classes else where he's allowed a degree

This conversation took place between Ruth and dean Griswold at Harvard University. Here showed how inequality between men and women with different when women want to move to another university because Ruth's husband is sick so Ruth has to move places and change universities but using the same degree. But here it showed that women cannot continue the degree in that way. But the rules are different for men, that men have no problem if they transfer to the university with the same degree and freely transfer to a university for any reason. 
Several people who have different views often feel right with what they say. It can be seen that the views and views of women are low compared to men. There are many facted showed that there are still many the limit of women and inequalities between women and men in social. It can be seen from the dialogue below:

\author{
Ruth : Mr. Greene, I want to be a lawyer. I want to represent \\ clients before the court in Pursuit of justice. You can see I \\ worked hard through school, I did everything, I Was \\ supposed to and I excelled. \\ Mr. Greene : The fact is, you know, we are close knit firm, almost like \\ family and the Wives, they get jealous.
}

In the dialogue, it was explained that there was a conversation between Mr. Greene and Ruth. Mr. Greene is someone who owns a law firm. It appears that Mr. Greene refused Ruth to become a lawyer at his law firm. The main reason of Ruth's gender is female, And Mr. Greene said that the wives would get jealous if he hired women at the law firm. The gesture that was displayed when Ruth spoke to Mr.Greene showed that Mr. Greene very clearly rejected Ruth by looking at Ruth's gender Standards like this are very detrimental to women with restrictions in social regarding women's rights that women should be trusted to do anything in social, However, many people think that women should work at home such as taking care of children, cooking. Meanwhile, men are not allowed to do work at home. There has been an inequality between men and women in society, where women should be able to do a job outside the home as well as men.

Civil rights are rights that should free people to think and express themselves without discrimination of gender, race, age. But this dialogue shows the inequality in civil rights.

Ruth :That is the legacy the government asks you to uphold today. You're being urged to 
protect the culture and traditions and morality of an america that no longer exists.

In the dialogue, Ruth gave her opinion about the current government. At that time, society was required to follow the laws in America which is very unfair based on gender that every human being should have the right to freedom based on gender. This conversation shows the inequality of civil rights.

Efforts to fight the law are a form of protection for women. Researcher analyzed how women's efforts to fight the law.

It's important to note that there are dangers associated with calling others out on their behavior. People may not like to have their viewpoints challenged; they may react in a negative or aggressive way, so if our instincts tell us that a situation is too risky, our safety is the priority. Often the best course of action when inequality is experienced is to alert an authority figure of a member of staff on public transport, or where relevant our teacher or our boss or friends and family. The more they are made aware these issues are happening, the more they will be encouraged to step in and be part of the solution.

Mr. Greene : A women, a mother and a jews to boot. I'm surprised that many let you through the door.

Ruth: One sent me to interview for the secretarial pool. Another told me, I'd be to busy at bake sales to be effective, one partners closes his clients in the locker room at this club, so he said I'd be out of the loop.

Mr. Greene :you must be livid.

The dialog above tells the conversation between Ruth and Mr. Greene. Mr. Greene is one of the people who have a law firm there. Here Ruth wants to become a lawyer at Mr.'s firm. Greene. In this dialogue, Mr. Greene asked why Ruth wanted to work with him. Because Mr. Greene knows that female lawyer are rarely accepted as lawyers. Ruth told Ruth's experience of how Ruth was looking for work, and many of the other 
firms refused because Ruth was a woman. And women do not have equality with men before the law to become a lawyer.

Join or start a school or university association for gender equality and women's leadership. There is power in a greater number of voices that tackle a particular problem meaning they are more likely to be heard. Helping to raise the profile of campaigns by other marginalized groups is an important part of ending discrimination. A great way to fight gender injustice is to form associations and support one another so you don't feel oppressed. In this case, it is shown how Ruth supports and discusses gender injustice that is felt by women.

$$
\begin{aligned}
& \text { Ruth : A jury convicted hoyt of second degree murder. And that's } \\
& \text { where our story begins. A great civil rights lawyer took up } \\
& \text { hoyt's appeal. Dorthy Kenyon. On what grounds? } \\
& \text { Roemer : The Florida's juries violated the U.S constitution cause } \\
& \text { there were only men on them. Kenyon said that if there were } \\
& \text { women on it, Hoyt may have been convicted of lesser crime } \\
& \text { like manslaughter. }
\end{aligned}
$$

Here Ruth is a professor who teaches lessons about gender injustice. In this class, the average person is a woman and here they discuss cases that have occurred against women.

The conversation shows that women can also be assertive and prove that in court Ruth can think rationally and express her opinion to protect against discrimination about how women do not get freedom.

Ruth: There are 178 laws that differentiate on the basis of sex, count them. The government did the favor of compiling them for you and while you're at it. I urge

you to read then. They're abstacles to our children's aspirations.

Judge Doyle : You're asking us to overturn nearly a century of precedent. 
Ruth : I'm asking you to set a new precedent, as courts have done before when the law is

outdated.

Judge Doyle : But in those cases, the courts had a clear constitutional handle. The word

"women" does not appear even once in the U.S constitution.

Ruth: nor does the word "freedom", your honor.

The conversation above shows that Ruth issued her opinion about legal freedom in America which in the constitution does not explain about women and there is no word freedom.

\section{CONCLUSIONS (خلاصة |خاتمة)}

The researcher concluded that four injustices were accepted by women. 1) inequality in economic right, 2) inequality in education right, 3) inequality in social right, 4) inequality in civil right. Inequality in economic rights women do not get decent work Inequality in society right because in general society demands women to be gentle. And the second inequality in social right is of the view that women do not have to work but only become mothers who take care of the housework and children. This perspective often occurs in society. The third is inequality in education right. Ruth is having a hard time wanting to become a lawyer. Because of her gender, Ruth is often rejected from work and every time there is a lesson in her class, Ruth is always the last one to answer lecturers' questions because men prioritize more than women. in the last, inequality in civil rights is that every human being should be able to express opinions and thoughts. Researcher also found the efforts made by Ruth. 1) Speak Out the Own Experiences, 2) support other campaigners, 3) expressing rational opinions. By sharing their own experiences with the interlocutor, it will make them know how women often get injustice. And also Ruth must expressing a opinion by winning a case that can change the legal perspective on women's rights. The third is how Ruth teaches about cases that occur against women. 
Based on the explanation above, it is concluded that gender inequality is based on a lack of belief in a gender. This injustice against women often occurs everywhere, such as in society, education. Because of the perspective that makes people think that women only work at home. So, there is a statement that is hard to get rid of. Actually, women and man have equal positions. Both have the same degree. Even if they have different functions, they are all, so that they can complement each other.

\section{BIBILIOGRAPHY (قائمة المراجع)}

Alex Mertin And Robert Hill. (1996). Modern Novel, New York. Prentince Hall Anthony Flew. (1992). Equality in Liberty and Justice. Newyork Baesley, Chris.( 1999). An Introduction To Feminist Theory. London: Sage Ben Michael. (2011) Feminist Theory: Examining Branches of Feminism, Newyork, Rutledge Taylor and Francis Group

Endraswara S . (2011), Metodologi Penelitian Sosiologi Sastra. Yogyakarta

Freedman Jane. (2001). Concepts in Social Sciences Feminism .Open University Press Buckingham Philadelphia

Faruk HT .(1994). Pengantar Sosiologi Sastra, Dari struktur Genetik sampai PostModernisme

Mario Klarer . (2004). An Introduction to Literary Studies Second Edition, (New York: Routledge)

Margono. (2007) . Metodology Penelitian, Jakarta Rineka Cipta

Nyoman Kutha Ratna. (2011), Teori, Metode, dan Teknik Penelitian Sastra, Yogyakarta: Pustaka Pelajar

Nyoman Kutha Ratna. (2010), Sastra and Cultural Studies, Representasi Fiksi \& Fakta, Yogyakarta

Siswantoro. (2010). Metode Penelitian Sastra. Yogyakarta.Pusaka Pelajar

Umar Khan. (2015) . Jenis Diskriminasi Gender. Amerika Serikat: Harcout Brace Javanovich College Publisher

Villarejo Amy, (2007). Film Studies the1Basi. (New York: Library of Congres,), Third Edition

Watkins Goloria. (2000). Feminism is For Everybody Passionate Politics Bell Books, Sounth End Press Cambritedge

William M. Evan, (1980). The Sociology of law, A Social Structural Perspektive, New York: The free press 